\title{
Actinopolymorpha pittospori sp. nov., an endophyte isolated from surface-sterilized leaves of an apricot tree (Pittosporum phylliraeoides)
}

Correspondence

Christopher M. M. Franco

chris.franco@flinders.edu.au

\author{
Onuma Kaewkla ${ }^{\dagger}$ and Christopher M. M. Franco
}

\author{
Department of Medical Biotechnology, School of Medicine, Flinders University, Bedford Park, \\ SA 5042, Australia
}

\begin{abstract}
A member of the genus Actinopolymorpha, designated PIP $143^{\top}$, was isolated from the leaves of an Australian native apricot tree (Pittosporum phylliraeoides). The isolate was a Gram-reactionpositive, aerobic actinobacterium, with a well-developed substrate mycelium that fragmented into small rods. Phylogenetic evaluation based on 16S rRNA gene sequences placed the isolate in the family Nocardioidaceae. Strain PIP $143^{\top}$ was most closely related to Actinopolymorpha cephalotaxi 106-2230 ${ }^{\top}$ (98.7\%) and Actinopolymorpha rutila YIM 45725 ${ }^{\top}$ (98.1\%).

Chemotaxonomic data, including cell-wall components, menaquinones and fatty acids, confirmed the affiliation of strain PIP $143^{\top}$ to the genus Actinopolymorpha. Phylogenetic analysis and physiological and biochemical studies, in combination with DNA-DNA hybridization studies, allowed the differentiation of strain PIP $143^{\top}$ from its closest phylogenetic neighbours with validly published names. Therefore, a novel species is proposed, with the name Actinopolymorpha pittospori sp. nov. The type strain is PIP $143^{\top}\left(=\mathrm{DSM} 45354^{\top}={\mathrm{ACM} 5288^{\top}=\text { NRRL B-24810 }}^{\top}\right.$ ).
\end{abstract}

The genus Actinopolymorpha was first described by Wang et al. (2001) and belongs to the family Nocardioidaceae, which includes the genera Nocardioides (Prauser, 1976), Aeromicrobium (Miller et al., 1991), Kribbella (Park et al., 1999), Marmoricola (Urzì et al., 2000) and Jiangella (Song et al., 2005). At the time of writing, the genus Actinopolymorpha contained four species, all of which were isolated from soil samples: A. singaporensis (Wang et al., 2001), A. rutila (Wang et al., 2008), A. alba (Cao et al., 2009) and A. cephalotaxi (Yuan et al., 2010). All members of the genus contain LL-diaminopimelic acid, but the major menaquinones and cell-wall sugars vary between the species: $A$. singaporensis and A. alba contain MK-9 $\left(\mathrm{H}_{6}\right)$, ribose, glucose and rhamnose (Wang et al., 2001; Cao et al., 2009); A. rutila contains MK-9 $\left(\mathrm{H}_{4}\right)$, ribose, glucose and galactose (Wang et al., 2008); and A. cephalotaxi contains MK-9 $\left(\mathrm{H}_{4}\right)$ and glucose (Yuan et al., 2010). The phospholipid pattern for these four species corresponds to type PI (Lechevalier et al., 1977).

During the course of our research on isolating endophytic actinobacteria from crop plants and native trees (Coombs \& Franco, 2003; Kaewkla \& Franco, 2010), an

tPresent address: Department of Biology, Faculty of Science, Mahasarakham University, Mahasarakham Province 44150, Thailand.

Abbreviation: meso- $\mathrm{A}_{2} \mathrm{pm}$, meso-diaminopimelic acid.

The GenBank/EMBL/DDBJ accession number for the $16 \mathrm{~S}$ rRNA gene sequence of strain PIP $143^{\top}$ is FJ805429.

A supplementary figure is available with the online version of this paper.
Actinopolymorpha-like strain, designated PIP $143^{\mathrm{T}}$, was isolated from a leaf sample from a native apricot tree (Pittosporum phylliraeoides), collected from the grounds of Flinders University, Adelaide, South Australia, and processed within $4 \mathrm{~h}$ of collection. Leaves were sterilized with $70 \%$ ethanol and $6 \%$ hypochlorite for $5 \mathrm{~min}$ each and rinsed repeatedly with sterile water, $10 \% \mathrm{NaHCO}_{3}$ for $10 \mathrm{~min}$ and again with sterile water. Crushed leaf tissue was placed on VL70 medium containing a mixture of 17 amino acids and solidified with $0.8 \%$ gellan gum (Hudson et al., 1989; Schoenborn et al., 2004). The medium was adjusted to $\mathrm{pH} 7.2$ and supplemented with $\left(\mathrm{ml}^{-1}\right) 20 \mu \mathrm{g}$ nalidixic acid and $100 \mathrm{U}$ nystatin to control bacterial and fungal contamination, respectively. Plates were kept in plastic sealed boxes, which contained wet paper towels to maintain moisture, and incubated at $27^{\circ} \mathrm{C}$. Strain PIP $143^{\mathrm{T}}$ was isolated from the leaf tissue after 11 weeks of growth on solid medium.

Extraction of genomic DNA from strain PIP $143^{\mathrm{T}}$ and amplification and sequencing of the $16 \mathrm{~S}$ rRNA gene were carried out as described previously (Coombs \& Franco, 2003). A nearly complete $16 \mathrm{~S}$ rRNA gene sequence (1407 bp) was obtained and analysed using BLAST (Altschul et al., 1997) and was subsequently aligned with $16 \mathrm{~S}$ rRNA gene sequences of representatives of related genera available from public databases using CLUSTAL x (Thompson et al., 1997). Phylogenetic trees were reconstructed by the neighbour-joining (Saitou \& Nei, 1987) and maximumparsimony (Fitch, 1971) tree-making methods using MEGA 
version 4 (Tamura et al., 2007). Pairwise distances for the neighbour-joining algorithm were calculated according to the Kimura two-parameter model (Kimura, 1980) and close-neighbour-interchange ( search level $=2$, random addition $=100)$ was applied in the maximum-parsimony analysis. Tree topology was evaluated by using bootstrap analysis (Felsenstein, 1985) with 1000 replications. The phylogenetic evaluation clearly showed that strain PIP $143^{\mathrm{T}}$ was a member of the genus Actinopolymorpha. The highest sequence similarity was observed with A. cephalotaxi I06$2230^{\mathrm{T}}$ (98.7\% 16S rRNA gene sequence similarity), followed by A. rutila YIM $45725^{\mathrm{T}}(98.1 \%)$, A. singaporensis IM $7744^{\mathrm{T}}$ $(97.7 \%)$ and A. alba YIM $48868^{\mathrm{T}}(97.3 \%)$. The affiliation between strain PIP $143^{\mathrm{T}}$ and its closest neighbour was supported by both the neighbour-joining and maximumparsimony algorithms, with bootstrap values of 97 and $89 \%$, respectively (Fig. 1 and Supplementary Fig. S1, available in IJSEM Online).

DNA-DNA relatedness between strain PIP $143^{\mathrm{T}}$ and its two closest phylogenetic neighbours was determined according to the colorimetric microdilution-plate method using biotinylated DNA (Ezaki et al., 1989; Kusunoki et al., 1991) and reciprocal experiments. DNA-DNA relatedness was calculated from four repeated experiments and expressed as a mean with the corresponding reciprocal values. DNA-DNA relatedness values between strain PIP $143^{\mathrm{T}}$ and A. cephalotaxi $\mathrm{I} 06-2230^{\mathrm{T}}$ and A. rutila YIM $45725^{\mathrm{T}}$ were 18.63 and $12.17 \%$, respectively, which were well below the $70 \%$ cut-off point recommended for the recognition of bacterial species (Wayne et al., 1987).

The DNA G + C content of strain PIP $143^{\mathrm{T}}$ was determined by HPLC (Mesbah et al., 1989). The DNA G + C content of strain PIP $143^{\mathrm{T}}$ was $69.6 \mathrm{~mol} \%$, which was similar to other members of the genus Actinopolymorpha with validly published names (66.6-69.5 mol\%) (Wang et al., 2001, 2008; Cao et al., 2009; Yuan et al., 2010).

For the analysis of whole-cell fatty acids, strain PIP $143^{\mathrm{T}}$ and the four type strains of species of the genus Actinopolymorpha were grown for 10 days at $25{ }^{\circ} \mathrm{C}$ in tryptic soy broth (Oxoid) at 150 r.p.m. and then harvested by centrifugation. Washed cells (100 mg) were saponified, the fatty acids were methylated and extracted and the fatty acid methyl esters were determined by the protocols described by Sasser (1990). Sherlock Microbial Identification System SITE1 version 6.0 was used for analysis. Extraction and purification of isoprenoid quinones was performed using the method of Collins et al. (1977), with analysis of the samples by reversedphase LC-MS employing UV detection and electrospray MS. The LC solvent system was 2-propanol/methanol (1:1) at a flow rate of $1.0 \mathrm{ml} \mathrm{min}{ }^{-1}$. Whole-cell hydrolysates were analysed for diaminopimelic acid isomers by TLC (Bousfield et al., 1985) and for sugars using the method of Hasegawa et al. (1983). The presence of mycolic acids was determined according to Minnikin et al. (1975, 1980). Acyl cell-wall analysis was performed according to Uchida \& Seino (1997). The diaminopimelic acid in whole-cell hydrolysates of strain PIP $143^{\mathrm{T}}$ was in the LL-configuration and the whole-cell sugars were ribose, glucose and galactose. Strain PIP $143^{\mathrm{T}}$ contained MK- $9\left(\mathrm{H}_{4}\right)$ as the predominant menaquinone, with MK-9 $\left(\mathrm{H}_{6}\right)$, MK-10 $\left(\mathrm{H}_{4}\right)$ and MK-10 $\left(\mathrm{H}_{8}\right)$ also present. A. cephalotaxi $106-2230^{\mathrm{T}}$ had a similar menaquinone composition, although it only contained glucose in its cell wall (Yuan et al., 2010). The whole-cell fatty acids of strain PIP $143^{\mathrm{T}}$ were chiefly of the iso- or anteiso-branched types (Table 1). The major cellular fatty acid of strain PIP $143^{\mathrm{T}}$ was iso- $\mathrm{C}_{16: 0}(29.16 \%)$, which was the same as for A. cephalotaxi I06-2230 ${ }^{\mathrm{T}}$ (40.46\%); however, A. cephalotaxi $\mathrm{I} 06-2230^{\mathrm{T}}$ also contained iso- $\mathrm{C}_{13: 0}$, anteiso- $\mathrm{C}_{17: 1} \omega 9 c, \mathrm{C}_{17: 0}, \mathrm{C}_{18: 0}$, $\mathrm{C}_{16: 1} \omega 7 c$ and anteiso- $\mathrm{C}_{17: 1} \mathrm{~B}$, which were not detected in strain PIP $143^{\mathrm{T}}$.

Morphological characteristics of the isolate were observed on eight different media: ISP 2, 3, 4, 5 and 7, Bennett's agar, half-strength potato dextrose agar and nutrient agar (Atlas, 1993), the results of which are given in Table 2. Strain PIP $143^{\mathrm{T}}$ showed a nocardioform morphology, with a well-developed substrate mycelium. Sparse aerial mycelia were formed on some media. The isolate did not produce diffusible pigments on any of the media used. The substrate mycelium was yellowish white on most media used, which is in contrast to A. cephalotaxi, the mycelium colour of which varies from yellow to brilliant orange.

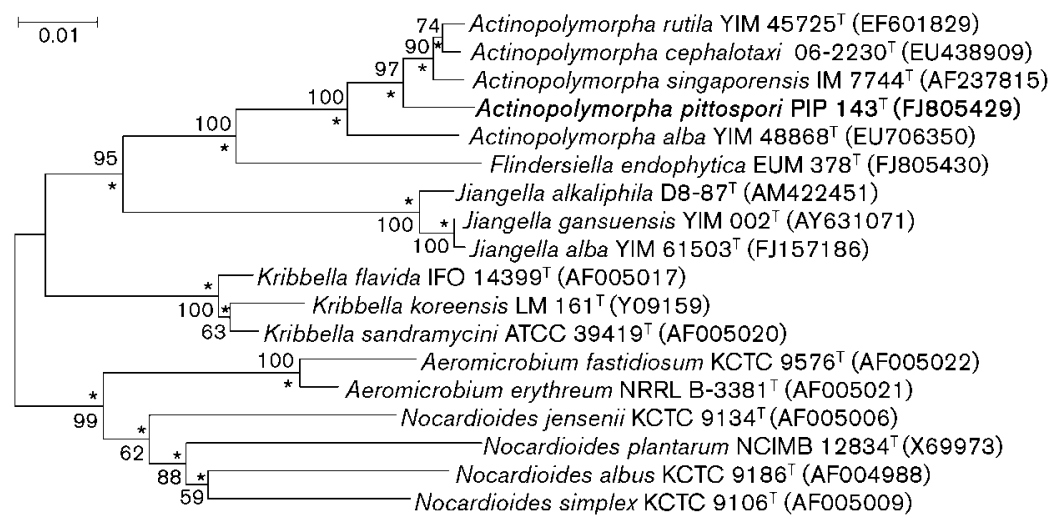

Fig. 1. Neighbour-joining tree based on $16 \mathrm{~S}$ rRNA gene sequences showing the relationships between strain PIP $143^{T}$ and selected members of the family Nocardioidaceae. Bootstrap values $(>50 \%)$ based on 1000 replications are shown at branch nodes. Asterisks indicate that the corresponding nodes were also recovered in the tree generated using the maximum-parsimony algorithm. Bar, 0.01 substitutions per nucleotide. 
Table 1. Whole-cell fatty acid compositions of strain PIP $143^{\top}$ and members of the genus Actinopolymorpha

Strains: 1, Actinopolymorpha pittospori sp. nov. PIP $143^{\mathrm{T}} ; 2$, A. cephalotaxi $\mathrm{I} 06-2230^{\mathrm{T}} ; 3$, A. rutila YIM $45725^{\mathrm{T}} ; 4$, A. singaporensis IM $7744^{\mathrm{T}}$; 5, A. alba YIM $48868^{\mathrm{T}}$. Data were taken from this study. Fatty acids representing $<0.5 \%$ of the total are not shown.

\begin{tabular}{|c|c|c|c|c|c|}
\hline Fatty acid (\%) & 1 & 2 & 3 & 4 & 5 \\
\hline $\mathrm{C}_{9: 0} 3-\mathrm{OH}$ & 0.71 & 1.16 & - & 1.15 & 0.62 \\
\hline iso- $\mathrm{C}_{10: 0}$ & - & - & 0.98 & - & - \\
\hline iso- $\mathrm{C}_{13: 0}$ & - & 0.91 & - & - & 0.50 \\
\hline iso- $\mathrm{C}_{14: 0}$ & 0.52 & 1.05 & 2.87 & 1.69 & 3.60 \\
\hline iso- $\mathrm{C}_{15: 1} \mathrm{G}$ & - & - & - & - & 0.76 \\
\hline iso- $\mathrm{C}_{15: 0}$ & 16.99 & 17.46 & 15.25 & 33.65 & 32.33 \\
\hline anteiso- $C_{15: 0}$ & 7.52 & 1.18 & 3.48 & 4.80 & 13.87 \\
\hline $\mathrm{C}_{16: 1} \omega 7 c$ alcohol & - & - & - & - & 1.79 \\
\hline $\mathrm{C}_{16: 0} \mathrm{~N}$ alcohol & - & - & 1.58 & - & - \\
\hline iso- $\mathrm{C}_{16: 0}$ & 29.16 & 40.46 & 35.82 & 25.30 & 10.90 \\
\hline $\mathrm{C}_{16: 1} \omega 9 c$ & - & - & - & 0.59 & - \\
\hline $\mathrm{C}_{16: 0}$ & 0.76 & 0.83 & 0.61 & 1.34 & - \\
\hline iso- $\mathrm{C}_{17: 1} \omega 10 c$ & - & - & 2.93 & - & 0.98 \\
\hline anteiso- $\mathrm{C}_{17: 1} \omega 9 c$ & - & 0.53 & 0.50 & - & 1.02 \\
\hline iso- $\mathrm{C}_{17: 0}$ & 16.35 & 10.64 & 9.97 & 12.11 & 10.86 \\
\hline anteiso- $\mathrm{C}_{17: 0}$ & 20.74 & 9.41 & 9.83 & 11.10 & 10.24 \\
\hline $\mathrm{C}_{17: 0}$ & - & 3.28 & 2.58 & - & - \\
\hline $\mathrm{C}_{17: 0}$ 10-methyl & 0.77 & 3.26 & 2.47 & 1.16 & - \\
\hline iso- $\mathrm{C}_{18: 0}$ & 1.61 & 0.66 & 0.69 & - & - \\
\hline $\mathrm{C}_{18: 1} \omega 9 c$ & 0.74 & 0.55 & - & - & - \\
\hline $\mathrm{C}_{18: 0}$ & - & 0.61 & 0.75 & - & - \\
\hline iso- $\mathrm{C}_{15: 1} \mathrm{H}$ & - & - & - & - & - \\
\hline$C_{19: 0}$ & - & - & 0.95 & - & - \\
\hline $\mathrm{C}_{18: 0} 2-\mathrm{OH}$ & - & - & 0.50 & - & - \\
\hline $\mathrm{C}_{16: 1} \omega 7 c$ & - & 1.57 & 1.85 & - & 3.50 \\
\hline anteiso- $\mathrm{C}_{17: 1} \mathrm{~B}$ & - & 2.55 & - & 1.23 & - \\
\hline iso- $\mathrm{C}_{17: 1}$ & 0.80 & - & - & - & - \\
\hline iso- $\mathrm{C}_{17: 1} \mathrm{I}$ & - & - & 1.17 & - & - \\
\hline iso- $\mathrm{C}_{18: 2} \omega 6,9 c$ & - & - & 0.85 & - & - \\
\hline iso- $\mathrm{C}_{19: 1} \omega 7 c$ & - & - & 0.54 & - & - \\
\hline iso- $\mathrm{C}_{20: 2} \omega 6,9 c$ & - & - & - & - & 5.08 \\
\hline $\mathrm{C}_{12: 0}$ aldehyde & - & - & - & - & - \\
\hline $\mathrm{C}_{16: 0}$ 10-methyl & 0.59 & 2.51 & - & 2.23 & - \\
\hline
\end{tabular}

Carbohydrate utilization was examined as described by Shirling \& Gottlieb (1966). Acid production from carbohydrates was examined by using the methods of Gordon et al. (1974). Growth at 4, 15, 27, 37 and $45{ }^{\circ} \mathrm{C}$, in 1, 3, 5, 10,15 and $20 \%(\mathrm{w} / \mathrm{v}) \mathrm{NaCl}$ and at $\mathrm{pH} 4-10$ (at intervals of one $\mathrm{pH}$ unit) was assessed after incubation at $27{ }^{\circ} \mathrm{C}$ for 7-14 days on ISP 2 medium (Kurup \& Schmitt, 1973). Hydrolysis of gelatin and catalase production were determined as described by Kurup \& Schmitt (1973).

The physiological properties of strain PIP $143^{\mathrm{T}}$ and $A$. cephalotaxi $\mathrm{I} 06-2230^{\mathrm{T}}$ were significantly different (Table 3 ) in terms of acid production from fructose, galactose, maltose, inositol, mannitol, sucrose, sorbitol, mannose, salicin and xylose, utilization of arabinose, raffinose, myoinositol and mannitol and growth in $5 \%(\mathrm{w} / \mathrm{v}) \mathrm{NaCl}$.

Based on the results of phylogenetic, phenotypic and chemotaxonomic analyses, strain PIP $143^{\mathrm{T}}$ represents a novel species of the genus Actinopolymorpha, for which the name Actinopolymorpha pittospori sp. nov. is proposed.

\section{Description of Actinopolymorpha pittospori sp. nov.}

Actinopolymorpha pittospori (pit.to.spo' ri. N.L. gen. n. pittospori named after the genus of the host plant Pittosporum phylliraeoides, from which the type strain was isolated).

Cells are Gram-reaction-positive, aerobic and non-acidalcohol-fast. Catalase-positive. Grows at $15-27{ }^{\circ} \mathrm{C}$, at pH 610 and in $1 \%(\mathrm{w} / \mathrm{v}) \mathrm{NaCl}$. Colonies are smooth to rugose and yellowish white to pale yellow. Substrate mycelium develops well on most media used but aerial mycelium is rarely formed. Diffusible pigments are not produced. Substrate mycelium is branched with irregular thickness which fragments into short chains or aggregates. In the later stages of growth, hyphae fragment to rod-like elements or Vshaped forms. Physiological properties are listed in Table 3 and whole-cell fatty acids are shown in Table 1.

The type strain, PIP $143^{\mathrm{T}}\left(=\mathrm{DSM} 45354^{\mathrm{T}}=\right.$ ACM $5288^{\mathrm{T}}$ $=$ NRRL B $-24810^{\mathrm{T}}$ ), is an endophytic actinobacterium, which was isolated from the leaves of Pittosporum

Table 2. Cultural characteristics of strain PIP $143^{\top}$

Colour determination based on Methuen Handbook of Colour (Kornerup \& Wanscher, 1978). Diffusible pigments were not detected on any media tested. -, Not detected.

\begin{tabular}{|lccc|}
\hline Medium & Growth & Aerial mycelium & Substrate mycelium \\
\hline Yeast extract malt extract agar (ISP 2) & Good & Moderate & Pale yellow \\
Oatmeal agar (ISP 3) & Poor & - & Yellowish white \\
Inorganic salt starch agar (ISP 4) & Poor & - & White \\
Glycerol asparagine agar (ISP 5) & Poor & - & Yellowish white \\
Tyrosine agar (ISP 7) & Poor & - & Yellowish white \\
Bennett's agar & Good & Moderate & Pale yellow \\
Half-strength potato dextrose agar & Good & Good & Yellowish white \\
Nutrient agar & Poor & - & Yellowish white \\
\hline
\end{tabular}


Table 3. Characteristics differentiating between strain PIP $143^{\top}$ and members of the genus Actinopolymorpha

Strains: 1, Actinopolymorpha pittospori sp. nov. PIP $143^{\mathrm{T}} ; 2$, A. cephalotaxi $\mathrm{I} 06-2230^{\mathrm{T}} ; 3$, A. rutila YIM $45725^{\mathrm{T}} ; 4$, A. singaporensis IM $7744^{\mathrm{T}}$; 5, A. alba YIM $48868^{\mathrm{T}}$. All data were from this study. All strains are positive for gelatin decomposition, catalase, utilization of glucose as sole carbon source, production of acid from arabinose, glucose and trehalose and growth with $1 \%(\mathrm{w} / \mathrm{v}) \mathrm{NaCl}$, at $\mathrm{pH} 6-10$ and at $27{ }^{\circ} \mathrm{C}$. All strains are negative for production of acid from 1,2propanediol and growth with 10, 15 and $20 \%(\mathrm{w} / \mathrm{v}) \mathrm{NaCl}$, at $\mathrm{pH} 4$ and at 4 and $45^{\circ} \mathrm{C}$. + , Positive; w, weakly positive; -, negative.

\begin{tabular}{|c|c|c|c|c|c|}
\hline Characteristic & 1 & 2 & 3 & 4 & 5 \\
\hline \multicolumn{6}{|c|}{ Carbon utilization of: } \\
\hline Arabinose & $\mathrm{w}$ & + & + & - & + \\
\hline Fructose & + & + & + & + & - \\
\hline Galactose & + & + & + & + & - \\
\hline Inositol & - & + & + & + & - \\
\hline Mannitol & - & + & + & + & - \\
\hline Raffinose & $\mathrm{w}$ & + & + & - & + \\
\hline \multicolumn{6}{|c|}{ Acid production from: } \\
\hline Fructose & - & + & + & + & + \\
\hline Dulcitol & - & - & $\mathrm{w}$ & $\mathrm{w}$ & - \\
\hline Galactose & - & + & + & + & + \\
\hline Maltose & - & + & + & + & + \\
\hline Mannose & $\mathrm{w}$ & + & + & + & + \\
\hline Inositol & - & + & $\mathrm{w}$ & + & w \\
\hline Mannitol & - & + & + & + & $\mathrm{w}$ \\
\hline Salicin & $\mathrm{w}$ & + & + & + & + \\
\hline Sucrose & - & + & + & + & + \\
\hline Xylose & $\mathrm{w}$ & + & + & + & + \\
\hline Adonitol & - & - & + & + & + \\
\hline Sorbitol & - & + & + & + & - \\
\hline \multicolumn{6}{|l|}{ Growth at/with: } \\
\hline $15{ }^{\circ} \mathrm{C}$ & + & + & $\mathrm{w}$ & - & - \\
\hline $37^{\circ} \mathrm{C}$ & - & - & + & + & - \\
\hline pH 5 & $\mathrm{w}$ & + & + & $\mathrm{w}$ & - \\
\hline $3 \% \mathrm{NaCl}$ & $\mathrm{w}$ & + & + & + & - \\
\hline $5 \% \mathrm{NaCl}$ & - & + & - & - & - \\
\hline
\end{tabular}

phylliraeoides growing on the campus of Flinders University, Adelaide, South Australia. The DNA G+C content of strain PIP $143^{\mathrm{T}}$ is $69.6 \mathrm{~mol} \%$.

\section{Acknowledgements}

The authors thank Greg Kirby for his assistance with the sampling of native plants, Daniel Jardine for menaquinone analysis and Kerry Gascoigne for scanning electron microscopy. Also, we are grateful to Max Aravena-Roman for performing the MIDI-FAME analysis, Yan$\mathrm{Ru}$ Cao for providing A. alba YIM $48868^{\mathrm{T}}$, Wen-Jun Li for providing A. cephalotaxi $\mathrm{I} 06-2230^{\mathrm{T}}$ and A. rutila YIM $45725^{\mathrm{T}}$ and Yue Wang for providing A. singaporensis IM $7744^{\mathrm{T}}$.

\section{References}

Altschul, S. F., Madden, T. L., Schäffer, A. A., Zhang, J., Zhang, Z., Miller, W. \& Lipman, D. J. (1997). Gapped BLAST and PSI-BLAST: a new generation of protein database search programs. Nucleic Acids Res 25, 3389-3402.

Atlas, R. M. (1993). Handbook of Microbiological Media. Edited by L. C. Parks. Boca Raton: CRC Press.

Bousfield, I. J., Keddie, R. M., Dando, T. R. \& Shaw, S. (1985). Simple rapid methods of cell wall analysis as an aid in the identification of aerobic coryneform bacteria. Chemical Methods in Bacterial Systematics. Society for Applied Bacteriology Technical Series, vol. 20, pp. 221-236. Edited by M. Goodfellow \& D. E. Minnikin. New York: Academic Press.

Cao, Y.-R., Jiang, Y., Wu, J.-Y., Xu, L.-H. \& Jiang, C.-L. (2009). Actinopolymorpha alba sp. nov., isolated from a rhizosphere soil. Int $J$ Syst Evol Microbiol 59, 2200-2203.

Collins, M. D., Pirouz, T., Goodfellow, M. \& Minnikin, D. E. (1977). Distribution of menaquinones in actinomycetes and corynebacteria. J Gen Microbiol 100, 221-230.

Coombs, J. T. \& Franco, C. M. M. (2003). Isolation and identification of actinobacteria from surface-sterilized wheat roots. Appl Environ Microbiol 69, 5603-5608.

Ezaki, T., Hashimoto, Y. \& Yabuuchi, E. (1989). Fluorometric deoxyribonucleic acid-deoxyribonucleic acid hybridization in microdilution wells as an alternative to membrane filter hybridization in which radioisotopes are used to determine genetic relatedness among bacterial strains. Int J Syst Bacteriol 39, 224-229.

Felsenstein, J. (1985). Confidence limits on phylogenies: an approach using the bootstrap. Evolution 39, 783-791.

Fitch, W. M. (1971). Toward defining the course of evolution: minimum change for a specific tree topology. Syst Zool 20, 406-416.

Gordon, R. E., Barnett, D. A., Handerhan, J. E. \& Pang, C. H. (1974). Nocardia coeliaca, Nocardia autotrophica, and the nocardin strain. Int J Syst Bacteriol 24, 54-63.

Hasegawa, T., Takisawa, M. \& Tanida, S. (1983). A rapid analysis for chemical grouping of aerobic actinomycetes. J Gen Appl Microbiol 29, 319-322.

Hudson, J. A., Schofield, K. A., Morgan, H. W. \& Daniel, R. M. (1989). Thermonema lapsum gen. nov., sp. nov., a thermophilic gliding bacterium. Int J Syst Bacteriol 39, 485-487.

Kaewkla, O. \& Franco, C. M. M. (2010). Nocardia callitridis sp. nov., an endophytic actinobacterium isolated from a surface-sterilized root of an Australian native pine tree. Int J Syst Evol Microbiol 60, 15321536.

Kimura, M. (1980). A simple method for estimating evolutionary rates of base substitutions through comparative studies of nucleotide sequences. J Mol Evol 16, 111-120.

Kornerup, J. \& Wanscher, H. (1978). Methuen Handbook of Colour, 3rd edn. Edited by D. Pavey. Fakenham, Norfolk: Cox \& Wyman Ltd.

Kurup, P. V. \& Schmitt, J. A. (1973). Numerical taxonomy of Nocardia. Can J Microbiol 19, 1035-1048.

Kusunoki, S., Ezaki, T., Tamesada, M., Hatanaka, Y., Asano, K., Hashimoto, Y. \& Yabuuchi, E. (1991). Application of colorimetric microdilution plate hybridization for rapid genetic identification of 22 Mycobacterium species. J Clin Microbiol 29, 1596-1603.

Lechevalier, M. P., de Bievre, C. \& Lechevalier, H. A. (1977). Chemotaxonomy of aerobic actinomycetes: phospholipid composition. Biochem Ecol Syst 5, 249-260.

Mesbah, M., Premachandran, U. \& Whitman, W. B. (1989). Precise measurement of the $\mathrm{G}+\mathrm{C}$ content of deoxyribonucleic acid by high performance liquid chromatography. Int J Syst Bacteriol 39, 159-167.

Miller, E. S., Woese, C. R. \& Brenner, S. (1991). Description of the erythromycin-producing bacterium Arthrobacter sp. strain NRRL 
B-3381 as Aeromicrobium erythreum gen. nov., sp. nov. Int J Syst Bacteriol 41, 363-368.

Minnikin, D. E., Alshamaony, L. \& Goodfellow, M. (1975). Differentiation of Mycobacterium, Nocardia, and related taxa by thin-layer chromatographic analysis of whole-organism methanolysates. J Gen Microbiol 88, 200-204.

Minnikin, D. E., Hutchinson, I. G., Caldicott, A. B. \& Goodfellow, M. (1980). Thin layer chromatography of methanolysates of mycolic acid containing bacteria. J Chromatogr A 188, 221-233.

Park, Y. H., Yoon, J. H., Shin, Y. K., Suzuki, K., Kudo, T., Seino, A., Kim, H. J., Lee, J. S. \& Lee, S. T. (1999). Classification of 'Nocardioides fulvus' IFO 14399 and Nocardioides sp. ATCC 39419 in Kribbella gen. nov., as Kribbella flavida sp. nov. and Kribbella sandramycini sp. nov. Int J Syst Bacteriol 49, 743-752.

Prauser, H. (1976). Nocardioides, a new genus of the order Actinomycetales. Int J Syst Bacteriol 26, 58-65.

Saitou, N. \& Nei, M. (1987). The neighbor-joining method: a new method for reconstructing phylogenetic trees. Mol Biol Evol 4, 406425.

Sasser, M. (1990). Identification of bacteria by gas chromatography of cellular fatty acids, MIDI Technical Note 101. Newark, DE: MIDI Inc.

Schoenborn, L., Yates, P. S., Grinton, B. E., Hugenholtz, P. \& Janssen, P. H. (2004). Liquid serial dilution is inferior to solid media for isolation of cultures representative of the phylum-level diversity of soil bacteria. Appl Environ Microbiol 70, 4363-4366.

Shirling, E. B. \& Gottlieb, D. (1966). Methods for characterization of Streptomyces species. Int J Syst Bacteriol 16, 313-340.

Song, L., Li, W.-J., Wang, Q.-L., Chen, G.-Z., Zhang, Y.-S. \& Xu, L.-H. (2005). Jiangella gansuensis gen. nov., sp. nov., a novel actinomycete from a desert soil in north-west China. Int J Syst Evol Microbiol 55, 881-884.
Tamura, K., Dudley, J., Nei, M. \& Kumar, S. (2007). MEGA4: molecular evolutionary genetics analysis (MEGA) software version 4.0. Mol Biol Evol 24, 1596-1599.

Thompson, J. D., Gibson, T. J., Plewniak, F., Jeanmougin, F. \& Higgins, D. G. (1997). The CLUSTAL_X windows interface: flexible strategies for multiple sequence alignment aided by quality analysis tools. Nucleic Acids Res 25, 4876-4882.

Uchida, K. \& Seino, A. (1997). Intra- and inter-generic relationships of various actinomycete strains based on the acyl types of the muramyl residue in cell-wall peptidoglycans examined in a glycolate test. Int J Syst Bacteriol 47, 182-190.

Urzì, C., Salamone, P., Schumann, P. \& Stackebrandt, E. (2000). Marmoricola aurantiacus gen. nov., sp. nov., a coccoid member of the family Nocardioidaceae isolated from a marble statue. Int J Syst Evol Microbiol 50, 529-536.

Wang, Y. M., Zhang, Z. S., Xu, X. L., Ruan, J. S. \& Wang, Y. (2001). Actinopolymorpha singaporensis gen. nov., sp. nov., a novel actinomycete from the tropical rainforest of Singapore. Int J Syst Evol Microbiol 51, 467-473.

Wang, Y.-X., Zhang, Y.-Q., Xu, L.-H. \& Li, W.-J. (2008). Actinopolymorpha rutila sp. nov., isolated from a forest soil. Int $J$ Syst Evol Microbiol 58, 2443-2446.

Wayne, L. G., Brenner, D. J., Colwell, R. R., Grimont, P. A. D., Kandler, P., Krichevsky, M. I., Moore, L. H., Moore, W. E. C., Murray, R. G. E. \& other authors (1987). International Committee on Systematic Bacteriology. Report of the ad hoc committee on reconciliation of approaches to bacterial systematics. Int J Syst Bacteriol 37, 463-464.

Yuan, L.-J., Zhang, Y.-Q., Yu, L.-Y., Sun, C.-H., Wei, Y.-Z., Liu, H.-Y., Li, W.-J. \& Zhang, Y.-Q. (2010). Actinopolymorpha cephalotaxi sp. nov., a novel actinomycete isolated from rhizosphere soil of the plant Cephalotaxus fortunei. Int J Syst Evol Microbiol 60, 51-54. 